\title{
ANATOMICAL LOCUS OF THE ANGULAR GYRUS: PRELIMINARY FINDINGS
}

\author{
Alyssa Everett, Barrett St. George, Nicole Denny, Frank Musiek
}

Department of Speech, Language, and Hearing Sciences, University of Arizona, Tucson, AZ, U.S.A.

Corresponding author: Frank Musiek, Department of Speech, Language, and Hearing Sciences, 1131 E $2^{\text {nd }}$ Street, Tucson, AZ 85719, U.S.A., e-mail: fmusiek@email.arizona.edu

\begin{abstract}
Background: The angular gyrus (AG) is an association area of the human cerebral cortex that plays a role in several processes, including auditory function. However, the precise anatomical location of the AG is not entirely clear. There are two common approaches for locating the AG based on gyral and sulcal landmarks: the 'parallel' and 'count-back' methods (as termed by the present authors). These two techniques do not always point to the same location on the cortex, thus making the macroanatomical locus of the AG rather ambiguous.
\end{abstract}

Material: Twenty high-resolution brain MRIs of normal, right-handed human subjects chosen from an online database (OASIS).

Methods: MRIs were sequentially chosen from OASIS and analyzed in MRIcron using two different visualization techniques: 1) skull-stripped surface renderings, and 2) serial sagittal slices. The AG was demarcated in the left and right hemisphere of each brain, as defined by the parallel and count-back methods. The reliability of each method for locating the AG was systematically assessed using both descriptive and inferential statistics, based on measures of hemispheric laterality.

Results and discussion: Examination of both methods for locating the AG showed poorer reliability in the left hemisphere compared to the right for both surface and more medial sites. Several anatomical factors were identified that compromised the reliability of the two methods.

Conclusions: Our finding of poor reliability between the parallel and count-back methods suggests that the AG is sometimes difficult to identify, particularly in the left hemisphere. This places the traditional gross anatomical methods for locating the AG in question. Development of new techniques to define this area of human neuroanatomy is needed.

Key words: brain $\bullet$ magnetic resonance imaging $\bullet$ neuroanatomy $\bullet$ temporal lobe $\bullet$ parietal lobe

\section{LA LOCALIZACIÓN ANATÓMICA DEL GIRO ANGULAR: ESTUDIOS PRELIMINARES}

\section{Resumen}

Introducción: Giro angular (AG) es un área que conecta la corteza cerebral y desempeña el papel en varios procesos, entre otros en actividades auditivas. Sin embargo, no es fácil indicar la precisa localización del AG. Existen dos métodos de localizar el AG, basándose en los puntos ganglionares y de surcos: el método "paralelo" y el método "count-back" (así llamada por los autores del presente trabajo). Estas dos técnicas no siempre llevan a la misma localización en la corteza cerebral que causa que la localización macroanatómica de AG es difícil de precisar.

Material: Veinte exámenes de alta definición de IRM del cerebro de las sanas personas diestras seleccionadas de la base de datos en línea (OASIS).

Métodos: Los exámenes de IRM fueron seleccionados de manera secuencial de la base OASIS y analizados en MRIcron usando dos distintas técnicas de visualización: 1) renderización de la superficie del cerebro y 2) de serie de planos sagitales. Las fronteras de la localización de AG fueron marcadas en el hemisferio izquierdo y derecho de cada cerebro examinado, de acuerdo con los resultados de ambos métodos - paralelo y count-back.

Resultados: El análisis de ambos métodos de localización AG demostró la menor credibilidad para el hemisferio izquierdo en comparación con el derecho, tanto en el superficie del cerebro, como en áreas más interiores. Se identificó varios factores anatómicos que influyeron en la conformidad de ambos métodos.

Conclusiones: Nuestra conclusión que se trata de la poca conformidad entre el método paralelo y count-back sugiere que AG es difícil de identificar, especialmente en el hemisferio izquierdo. Esto pone en cuestión los tradicionales métodos anatómicos generales que sirven para la localización de AG. Hay que buscar nuevos métodos para estudiar esta rama de neuroanatomía humana. 


\section{АНАТОМИЧЕСКОЕ РАСПОЛОЖЕНИЕ УГЛОВОЙ ИЗВИЛИНЫ: ПРЕДВАРИТЕЛЬНЫЕ ИССЛЕДОВАНИЯ}

\section{Изложение}

Введение: Угловая извилина (AG) является областью, соединяющей кору головного мозга человека, и играет роль в нескольких процессах, в том числе в слуховых функциях. Однако точное положение AG нелегко определить. Существуют два метода определения места расположения AG, опираясь на пункты извилин мозга и бороздовые пункты: «параллельный» метод и «count-back» (так назвали его авторы этой работы). Применяя их, не всегда получаем один и тот же результат относительно местоположения в коре головного мозга, а это приводит к тому, что точное определение макроанатомического расположения AG представляет собой сложную задачу.

Материал: Двадцать МРТ головного мозга высокого разрешения. Исследованиям были подвергнуты здоровые праворукие люди, выбранные из интернет-базы (OASIS).

Методы: Результаты исследований MPT выбирались последовательно из базы OASIS и анализировались с помощью MPTcron, используя два разных метода визуализации: 1) рендеринг поверхности головного мозга, 2) из серии стрелковых слоев. В соответствии с результатами обоих методов - параллельного и count-back - на левом и правом полушарии каждого подвергнутого исследованию мозга были обозначены границы местоположения AG. Степень достоверности обоих методов установления местоположения AG оценивалась систематически с помощью описательной и дедуктивной статистики, опираясь на измерения состояния преобладания правого или левого полушария.

Результаты и дискуссия: Анализ обоих методов определения местоположения AG показал, что по сравнению с правым полушарием в случае левого полушария степень достоверности ниже как на поверхности головного мозга, так и в более глубоких областях. Выявлено несколько анатомических факторов, которые влияли на совместимость обоих методов.

Выводы: Наш вывод, согласно которому степень совместимости методов параллельного и count-back маленькая, подсказывает, что AG трудно идентифицировать, особенно в случае левого полушария. Данный факт ставит под сомнение традиционные общие анатомические методы определения местоположения AG. Следует искать новые способы с целью исследовать эту отрасль нейроанатомии человека.

Ключевые слова: мозг • магнитно-резонансная томография • нейроанатомия • височная доля • теменная доля

\section{ANATOMICZNA LOKALIZACJA ZAKRĘTU KĄTOWEGO: BADANIA WSTĘPNE}

\section{Streszczenie}

Wstęp: Zakręt kątowy (AG) jest obszarem łączącym korę mózgową u człowieka i odgrywa rolę w kilku procesach w tym w czynnościach słuchowych. Jednakże dokładne położenie AG nie jest łatwe do określenia. Są dwie metody służące do określenia lokalizacji AG w oparciu o punkty zwojowe i bruzdowe: metoda „paralelna” i metoda „count-back” (nazwana tak przez autorów tej pracy). Te dwie techniki nie zawsze prowadzą do tej samej lokalizacji w korze mózgowej, co powoduje, że makroanatomiczne położenie AG jest trudne do sprecyzowania.

Materiał: Dwadzieścia wysokiej rozdzielczości badań MRI mózgu, u zdrowych praworęcznych osób wybranych z bazy internetowej (OASIS).

Metody: Badania MRI były wybierane sekwencyjne z bazy OASIS i analizowane w MRIcron używając dwóch różnych technik wizualizacji: 1) renderingów powierzchni mózgu oraz 2) z serii warstw strzałkowych. Granice położenia AG zostały oznaczone na lewej i prawej półkuli każdego badanego mózgu zgodnie z wynikami obu metod - paralelnej i count-back. Systematycznie oceniano stopień rzetelności obu metod lokalizacji AG za pomocą statystki opisowej i dedukcyjnej, w oparciu o pomiary stanu przewagi jednej lub drugiej półkuli.

Wyniki i dyskusja: Analiza obu metod lokalizowania AG wykazała mniejszą wiarygodność dla lewej półkuli w porównaniu z prawą zarówno na powierzchni mózgu jak i w obszarach bardziej wewnętrznych. Zidentyfikowano kilka czynników anatomicznych, które wpływały na zgodność obu metod. 
Wnioski: Nasz wniosek mówiący o małej zgodności pomiędzy metodami paralelną i count-back sugeruje, że AG jest trudny do zidentyfikowania, szczególnie w lewej półkuli. To poddaje pod wątpliwość tradycyjne ogólne metody anatomiczne służące do lokalizacji AG. Należy szukać nowych technik w celu zbadania tej gałęzi neuroanatomii człowieka.

Słowa kluczowe: mózg • obrazowanie za pomocą rezonansu magnetycznego $\bullet$ neuroanatomia $\bullet$ płat skroniowy $\bullet$ płat ciemieniowy

\section{Background}

In the central auditory nervous system there are a number of anatomical regions that are often referred to as secondary or association auditory areas. It seems likely that the angular gyrus (AG) may fit into these secondary categories. The AG is not one of the structures commonly associated with auditory areas in the brain, but interestingly it does play a role in semantically processing auditory input, activating during auditory word tasks and (in some populations) during auditory hallucinations [1-6]. In this article, the location of the AG as well as some of its auditory and non-auditory functions will be elucidated. As will be shown, the AG, like many other areas of the brain, is variable in its anatomy. In fact, there are even some misinterpretations of its actual locus. In our review of the literature, the gross anatomical location of the AG was found to be ambiguous. Natural variability of the cortical surface in auditory regions affects the localization of the AG, and so classic approaches to locating this structure may be less than ideal. Through our own MRI analysis, we were able to compare the validity of two common methods of finding the AG on the human cortex. Due to its anatomical variation and its auditory role, especially for speech perception, this account of the AG seems appropriate and timely.

The AG, also commonly referred to as Brodmann's area 39 , is located in the posterior inferior portion of the parietal lobe. Brodmann's areas were determined by German physician Korbinian Brodmann in 1909. Brodmann defined different brain areas based on the cytoarchitectural organization of neurons. His idea was to establish a map and numbering system of the cortex based on its anatomical structures in order to better localize and distinguish the different areas of the brain [7]. The posterior inferior area of the parietal lobe is a surface structure that is also shared with the supramarginal gyrus (Brodmann's area $40)$. These two structures are connected by the local arcuate [8]. The local arcuate refers to the arcuate fasciculus which is a bundle of axons connecting the temporal and parietal cortices to the frontal lobe.

Identifying the precise location of the AG is not well agreed upon due to the variability of individual brains and the different methods used to locate it. Webster [9] reported that the AG comprises the posterior portion of the inferior parietal lobe and borders the occipital and temporal lobes. Specifically, it is located posteriorly and inferiorly in relation to Brodmann's area 40 (the supramarginal gyrus). In contrast, Musiek and Baran [10] reported the AG's location as being posterior superior to the supramarginal gyrus in the cortex. However, according to Rubens [11], if the posterior aspect of the Sylvian fissure has an ascending ramus (upward turn), this can cause the AG to be located inferiorly to the supramarginal gyrus, in agreement with Webster [9] (Figure 1). Tzourio-Mazoyer et al. [12] identified the AG "anteriorly by the angular sulcus and caudally by the occipitoparietal line". The intraparietal sulcus is the dorsal boundary of the AG. This has been confirmed using cytoarchitectonics [13].

There is a variety of software used to automatically parcellate and label distinct anatomical brain areas. These automated brain segmentation algorithms are included in common neuroimaging programs such as FreeSurfer, SPM8, VBM8, and FSL. Although automatic algorithms perform much quicker segmentations than can be done manually, no such algorithm is perfect. For example, Eggert et al. [14] found sizable differences in mean gray matter volumes of the same brains analyzed with VBM8, SPM8, FSL, and FreeSurfer. Some of these algorithms were more accurate, and some more reliable at segmenting cortical areas [14]. As a result, the different segmentation procedures cannot be compared with certainty. Clearly, automated brain segmentation will produce some errors and/or inconsistencies, so having reliable cross-checks - such as simple visualization techniques - may be helpful in determining the accuracy and reliability of automatic segmentation. Two visualization techniques for locating the AG are discussed in this paper.

Despite being well-studied, there is a discrepancy in the literature regarding the precise location of the AG on the human brain. Eberstaller [15] stated that the AG is "bent around the upper end of the superior temporal sulcus". Looking at the cortex from a sagittal perspective, the AG resembles a horseshoe around the superior temporal sulcus [16]. Brodmann [17] described the AG as a "widening

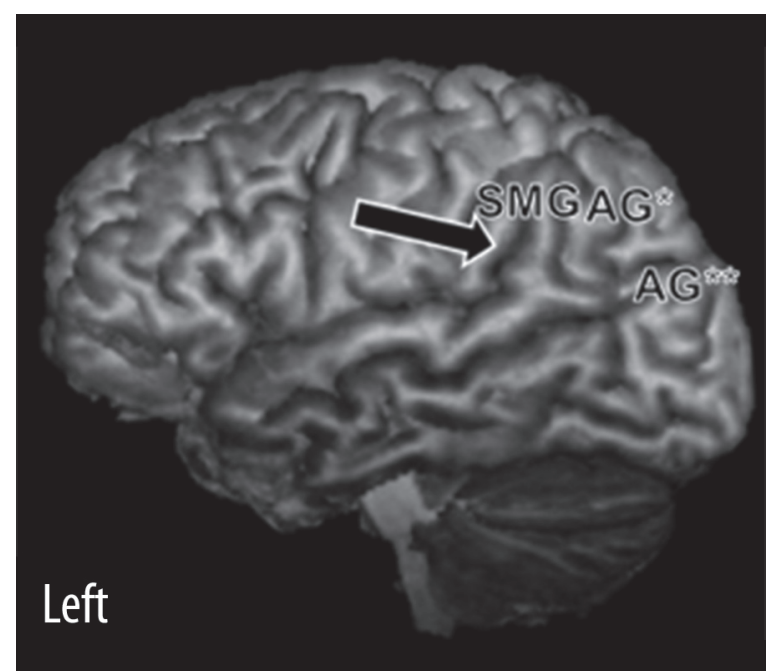

Figure 1. The posterior ascending ramus of the Sylvian fissure (arrow) sometimes created a separation between the SMG and the AG (OAS1_0050LH). This results in the parallel and count-back methods pointing to two different locations on the cortex: $\mathrm{AG}^{*}$ is the location of the angular gyrus according to the count-back method; $A^{* *}$ is the location according to the parallel method 


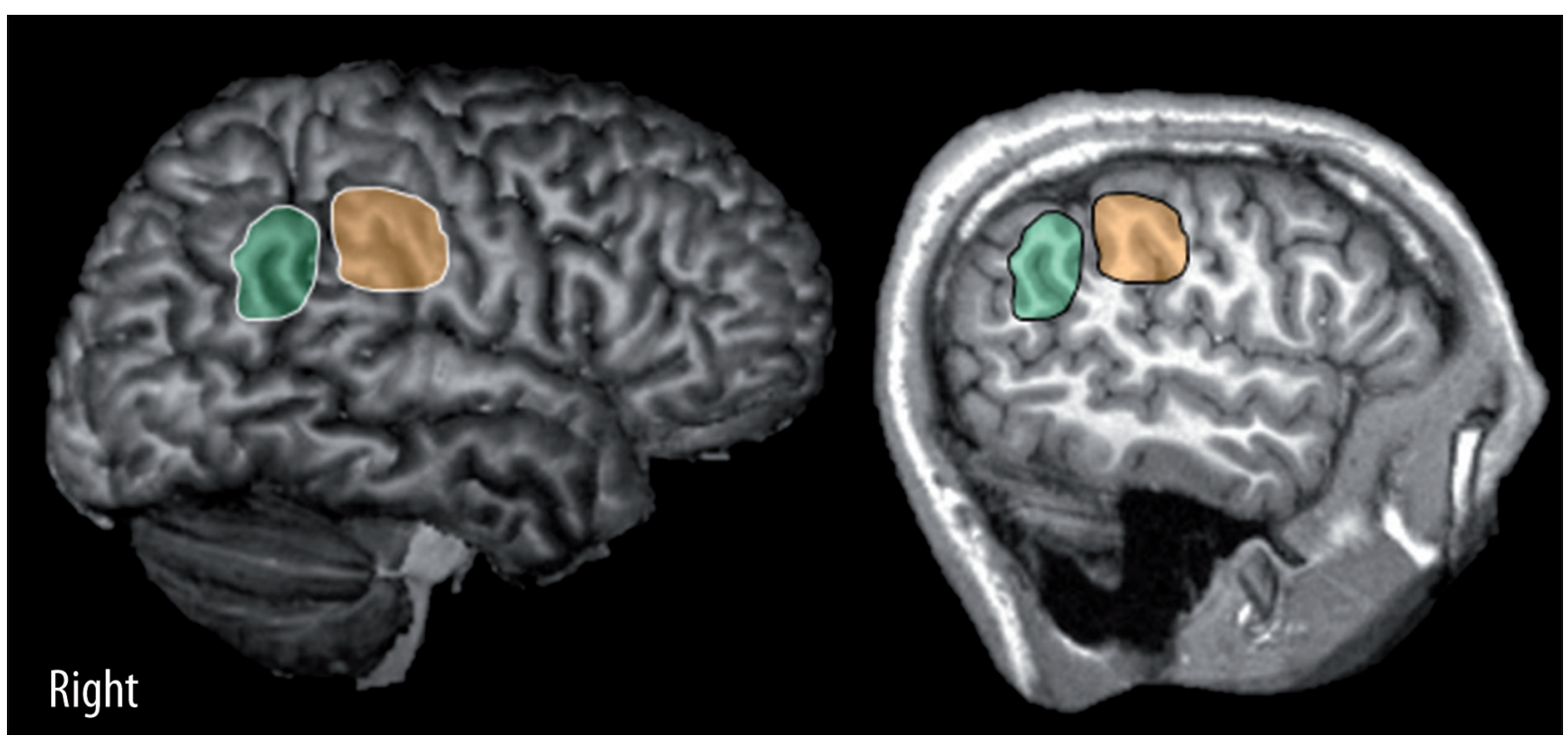

Figure 2. Location of the angular gyrus (AG, green) in relation to the supramarginal gyrus (SMG, orange). At left is the skull-stripped surface rendering and at right is a sagittal slice at $10-20 \mathrm{~mm}$ depth providing a more medial view. In these right hemisphere images, the parallel and count-back methods are in agreement. The images were generated from crosssectional data on the OASIS database for subject OAS1_0029RH (http://Www.oasis-brains.org/)

around the posterior end of the superior temporal sulcus". Ribas [18] described the location of the AG similarly: "the angular gyrus encircles the horizontal distal portion of the superior temporal sulcus". Since the superior temporal sulcus (STS) essentially runs parallel to the Sylvian fissure, we will refer to the comparable definitions of Eberstaller, Brodmann, and Ribas [15,17,18] as the "parallel method" of locating the AG. Another, perhaps more common, method for locating the AG is one that uses the supramarginal gyrus (SMG) as a reference point. With this method, the AG is found by counting back one gyrus posterior from the SMG [17]. We will refer to this description as the "count-back" method of locating the AG. However, these two methodologies have inherent problems due to the variability of the anatomy of the human cortex. Two major sources of this variability, which can exist between brains and between hemispheres, are differences in gyral patterns and sulcal depth. Because gyri and sulci are not consistent across human brains, the actual location of the AG cannot be accurately defined. We therefore argue that these two common methods of finding the AG (count-back and parallel) do not correspond to the same precise anatomical location in all human brains. Here, using MRI image analysis across a number of brains, we tested whether both methods agreed on the location of the AG. This is an empirical approach to determining the reliability of the two methods. It is important to find a reliable method for locating structures in the brain so one can accurately describe its function, and more precisely interpret the effects of lesions, as well as being useful for evoked potential and functional imaging studies.

We presumed that the parallel and count-back methods are unlikely to point to the same location in all brains due to the anatomical variability of gyri and sulci between individuals. Also, a presumption was made regarding brain asymmetry (i.e., laterality effects). We expected that the left hemisphere would, compared to the right, show greater disagreement between the two methods since the literature notes more fissurization and complex cortical folding in the perisylvian region of the left hemisphere [25-27].

Anatomical variability means that one brain may indicate that both methods of locating the AG (parallel and countback methods) agree (Figure 2), whereas another brain can show the opposite, in which the parallel and count-back methods disagree (Figure 3).

Through the AG's association with adjacent lobes (occipital, parietal, and temporal), the AG integrates information from vision, touch, and hearing, respectively. A review of the AG suggests its most prominent and consistent function across multiple studies is semantic processing, more so in the left hemisphere than in the right [19]. The AG is also involved in reading and speech comprehension. Interestingly, studies have shown that the AG becomes activated while reading complete sentences or comprehending speech, but not while reading single words out loud in isolation [19]. These findings support the idea that the AG's role in semantic processing may also occur at the level of sentence comprehension in both the visual and auditory modalities. In addition to its activation during language processing tasks, the AG has also been found to become activated during numerous cognitive tasks, including numerical processing, memory retrieval, attention, spatial processing, and theory of mind. Grabner et al. (2013) suggest that the functional capabilities of the left AG include memory storage of mathematical solutions, shown by activation in fMRI studies [20]. But due to its connections with multiple sensory locations in the cortex, the AG's functions are hard to determine and are often not clear. The AG receives input from the primary visual cortex in the occipital lobe. Somatosensory information is also sent to the AG from the postcentral gyrus, specifically Brodmann's areas 3,2, and 1, which are responsible for balance and touch [9]. Auditory information is processed in the AG via activation of associations from the auditory cortex [18]. Musiek and Baran [10], in 


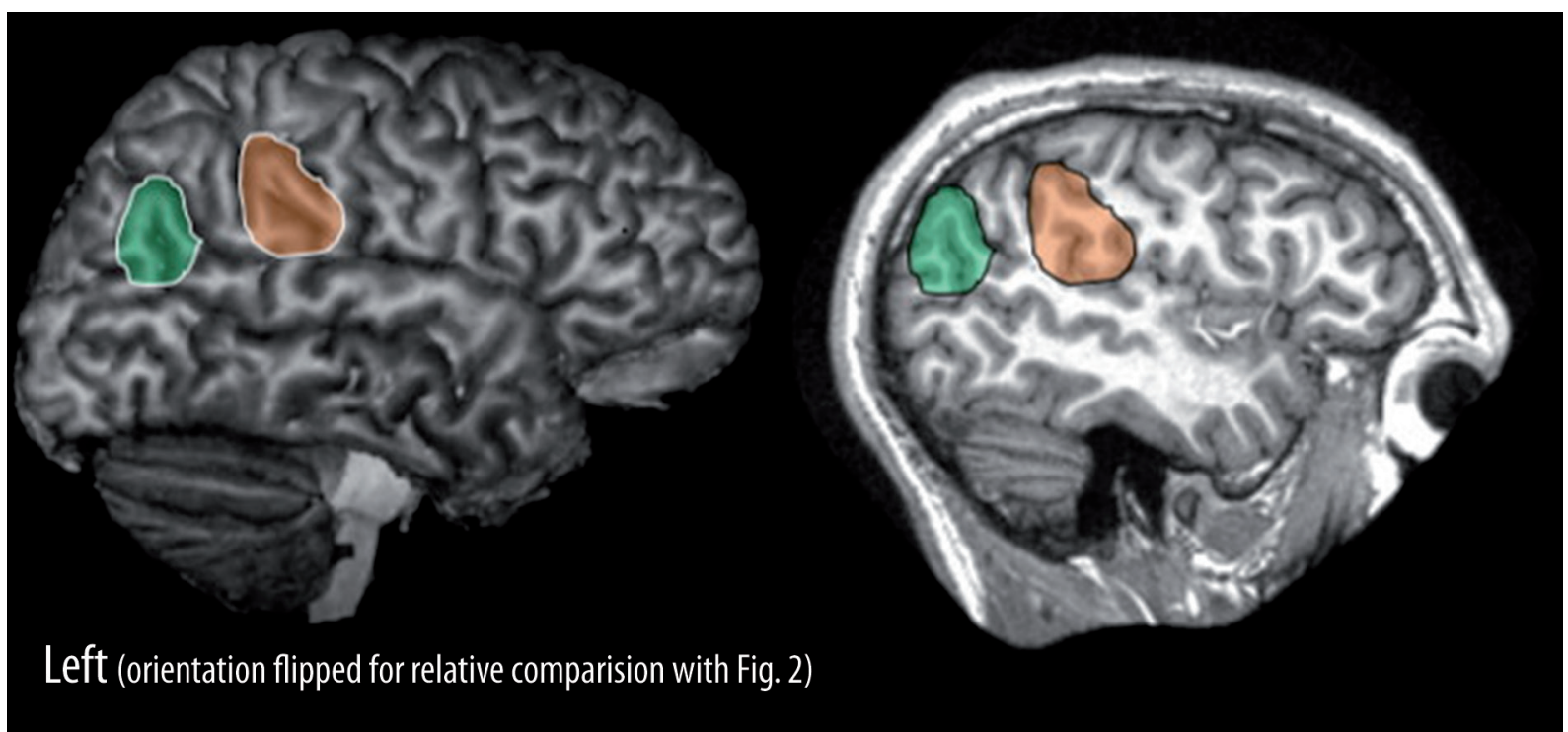

Figure 3. Disagreement between the parallel and count-back methods for locating the AG. In these left hemisphere images (taken from OAS1_0029LH), there is a prominent gyrus intervening between the SMG (orange) and AG (green). The images have been flippēd horizontally for comparison with Figure 2

agreement with Berry et al. [21], reported the AG might be viewed as an "association auditory cortex." In general, it is likely that the AG reflects some type of auditory representation - an auditory footprint.

Throughout the literature, the AG is commonly referred to as a multimodal hub, but how does it contribute to the processing of auditory stimuli? Demonet et al. [1] examined brain activation of nine right-handed healthy individuals using positron emission tomography and three types of stimuli: tonal, word, and phonological. The investigators found the greatest activation occurred during word testing, noting activation of the posterior part of the left supramarginal gyrus and spreading to the border of the supramarginal and angular gyri [1]. The findings of this study allow us to infer that the AG is capable of semantically processing auditory input.

Also relevant here is the work of Binder et al. [22], who gathered fMRI data in 12 normal right-handed individuals ( 6 male and 6 female) under passive and active listening during word and tonal stimulation. The active word task was used in which the name of an animal was presented auditorily to the listener who then had to decide if the animal was found in the United States and used by people. This task required functions of speech, semantics, and word processing. The active tonal task involved presenting tone sequences in which the listener had to press a button to identify the sequence which had two non-sequential high frequency tones. In order to push the button correctly, both tasks required auditory processing, attention, working memory, and motor functions. For the passive word and tonal stimulation tasks, the listener was required to listen to words and tones and indicate when the sounds began and ended. Using the results from fMRI, the researchers concluded that the AG was significantly more activated during the active auditory word tasks compared to tonal stimulation. The other tasks did not significantly activate the AG region; in these cases, activation occurred primarily along the auditory cortex and the STS.
Interestingly, in schizophrenic individuals there is a relationship between functional abnormalities in the AG and auditory verbal hallucinations [23]. The participants in this study included 26 Chinese males diagnosed with schizophrenia (13 of whom experienced auditory verbal hallucinations and 13 who did not); 13 normal matched individuals acted as the control group. Auditory stimuli included recorded male speech that simulated hallucination-like voices producing different types of commands. As participants were scanned, auditory stimuli were presented binaurally; however, the delivery of the signals was designed to create a lateralization effect, similar to that of the head-related transfer function. Participants were required to report whether they heard the voices in the left or right ear. When the stimulus was lateralized to the left side, fMRI results indicated a greater activation of the left hemisphere AG in the auditory verbal hallucination group compared to the no hallucination group. In addition, results suggested that there is a significant decrease in the asymmetry of language activation sites in those with hallucinations compared to the control group. It can be concluded that dysfunction in the left AG may cause auditory abnormalities that can be seen through imaging. The purpose of this paper is to determine the reliability of the count-back and parallel methods for locating the AG and discuss its functional significance, specifically its auditory role.

\section{Material and methods}

Brain images in our study were drawn from the crosssectional Open Access Series of Imaging Studies (OASIS) dataset by Marcus et al. (http://www.oasis-brains.org) [21]. Twenty healthy right-handed individuals (10 males, $10 \mathrm{fe}$ males; age 18 to 50 years; mean $=26, S D=8.12$ ) were chosen and analyzed. For reference, OASIS subjects in the crosssectional database were arranged by subject number from least to greatest. Inclusion criteria was age 18-50 years old with no clinical dementia rating (CDR). We arbitrarily chose 10 males and 10 females from the first 100 subjects 
listed; the 10 males had subject IDs of OAS1_0029 to 0102 and the 10 females had IDs of OAS1_0025 to 0057. According to the description in reference [21], image acquisition involved using a multiple T1-weighted magnetization-prepared rapid gradient-echo (MP-RAGE) technique on each subject in a single session on a 1.5-T Vision scanner (Siemens, Germany). MP-RAGE parameters were optimized for gray-white contrast. Acquired images were viewed slice-by-slice along sagittal, coronal, and axial planes to ensure images were free of artifacts and processing errors. Images with severe flaws were excluded from the data set. Additional information about image acquisition, post-processing, and quality control can be found in the original OASIS journal article [21].

\section{Procedure}

MRIs were examined using MRIcron software version 6.6 2013. We used two different techniques to view the MRI data: 1) skull-stripped surface renderings to provide an external view of the cortex; and 2) serial sagittal slices (inspected orthogonally) to provide a more medial view of the cortex (10-20 mm depth). Utilizing both techniques allowed us to compare our results to cadaver studies and to determine if the depth of sulci affected our findings.

The posterior ends of the Sylvian fissure (SF) and superior temporal sulcus (STS) were inspected orthogonally in serial sagittal slices for both right and left hemispheres. Sagittal slices were viewed by navigating laterally-to-medially until both angular and supramarginal gyri became visible on a single sagittal slice. The most lateral slice we viewed was the point at which both the SF and the STS first became visible. The most medial slice was identified as the point at which the opening of the insula first became visible. We did not look at sagittal slices that were medial to the opening of the insula because the structure of interest (the AG) is located superficially in relation to the insula on the dorsolateral aspect of the cortex. Additionally, skull-stripped surface renderings were viewed from both the left and right sides (270 and 90 degrees respectively) to offer a complete view of the SF, STS, and inferior parietal lobule (IPL) on the convex cortical surface.

The skull-stripped surface renderings were inspected independently from the serial sagittal images in order to offer a comparison between superficial and more medial brain analysis (discussed further in the Analysis and Discussion sections).

\section{Analysis}

All images on OASIS are in 16-bit big-endian Analyze 7.5 format and have been anonymized to allow public distribution. Sagittal images were averaged and co-registered in resampled $1 \mathrm{~mm}$ isotropic voxels in native space from the individual brain scan images. For more detail on MRI image processing, refer to [21]. To obtain surface rendered images, the OASIS images were converted to NiFTI format saved in native space. The images were then skullstripped in SPM12 software. The rendered brains consisted of a c1 and c2 (grey matter and white matter) mask of the original native space MRI to retain original image intensity values. MRIcron software was used to render left and right hemispheres at azimuths of 270 and 90 degrees respectively, with elevation at zero. The volume rendering settings were set to an air/skin threshold of 30\% (lower percentage equals a more superficial landing site) and a search depth of $8 \mathrm{~mm}$.

\section{Results}

Agreement was defined by the convergence of both methods (parallel and count-back) when the posterior superior extension of the STS terminated one gyrus directly posterior to the SMG (Figure 2). The allowed disparity was ten voxels $(10 \mathrm{~mm})$. We expected that both methods for locating the AG would not point to the same location in all brains, with more discordance occurring in the left hemisphere, compared to the right. Our results partially support these expectations in that a large proportion of the brains we examined exhibited disagreement when the results of the parallel and count-back methods were compared. However, there was no statistically significant difference between the right and left hemispheres in terms of proportion of disagreement. We used an alpha level of 0.05 for all statistical tests.

\section{Skull-stripped surface renderings}

Skull-stripped surface renderings were used to provide an external view of the cortex, approximating post-mortem or cadaver inspection. According to this inspection technique, disagreement between the count-back and parallel methods for locating the AG (disparity $>10 \mathrm{~mm}$ ) was confirmed in $9 / 20(45 \%)$ brains in the left hemisphere, and 4/20 (20\%) in the right hemisphere. A Fisher's exact test was performed to determine the association between methodological disagreement and hemisphere. There was a trend towards statistical significance ( $P=0.088$, one-tailed FET).

\section{Serial sagittal slice inspection}

Serial sagittal slices were used to provide a more medial view of the brain (10-20 mm). According to this inspection technique, the two methods disagreed (disparity $>10$ $\mathrm{mm}$ ) in the left hemisphere in 12/20 (60\%) brains and 9/20 (45\%) brains in the right hemisphere. A Fisher's exact test was performed to determine the association between methodological disagreement and hemisphere. There was no statistically significant difference ( $P=0.264$, one-tailed FET).

The morphometry of the STS was found to be highly variable in the brains examined, especially in the left hemisphere (Figure 4). This finding is in agreement with Connolly [25], who investigated the external morphology of 60 human brains and discovered that the left STS separates into multiple sulci more often than the right STS (which is usually continuous). In our investigation, we were unable to accurately identify the full course of the STS in the left hemisphere in several brains (0043; 0051; 0095). Consequently, this leftward lateralized variability of the STS is responsible for some cases of disagreement between the parallel and count-back methods. The greater incidence of disagreement between the parallel and count-back methods found in the left hemisphere can be partially attributed to this anatomical phenomenon of considerable morphologic variability in the left STS. 


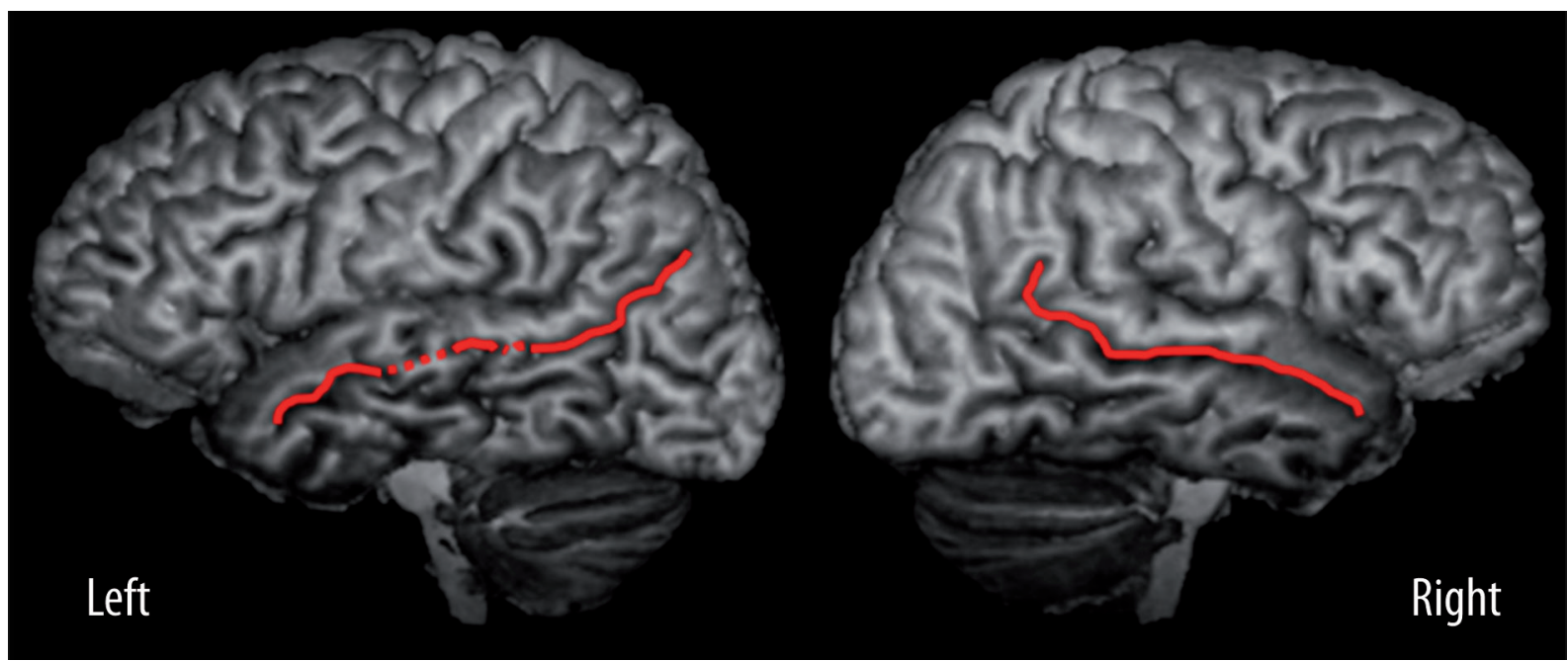

Figure 4. Example of an indistinguishable superior temporal sulcus (STS) in the left hemisphere (red dotted line). In comparison, the STS is more well-defined in the right temporal lobe (continuous red line). Cortical surface images generated from data for subject OAS1_0051LH and 0050RH

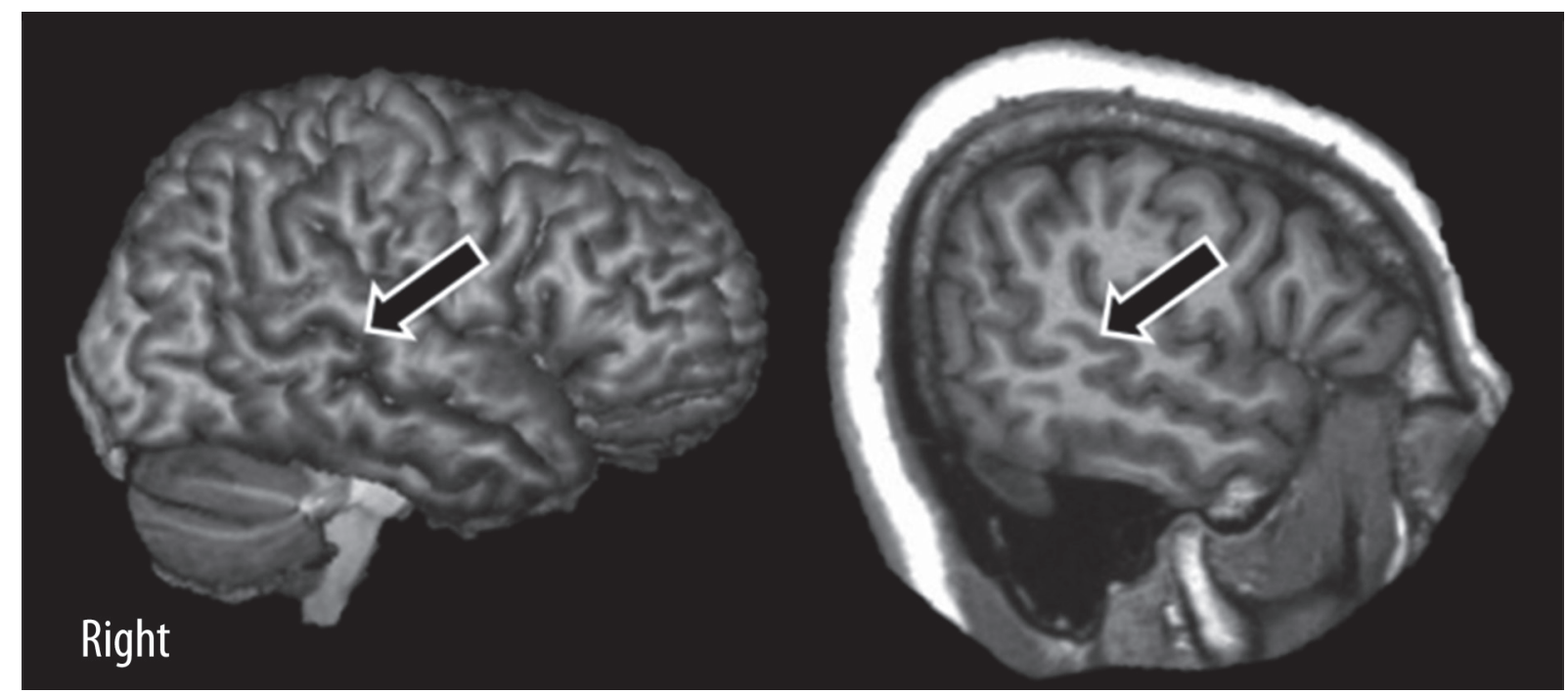

Figure 5. On the external surface of this brain, the STS is continuous (arrow, left image), but more medially (10-20 mm) there is a break in the STS (arrow, right image). Images generated from data for subject OAS1_0040RH

We found more disagreement between the methods when looking $10-20 \mathrm{~mm}$ medially in the brain (via sagittal slice inspection). In several instances (0038LH; 0043LH, 0051LH), we noted an interruption in the STS, evidenced by a perpendicular gyrus intervening somewhere along its anterior-to-posterior course. These interruptions were sometimes imperceptible when viewing the external surface of the brain. However, when looking more medially, the break became apparent (Figure 5, subject 0040RH. For this reason, we found better concurrence between the methods when looking at the surface rendered brain images. This is important to note because the parallel and countback methods for locating the AG were first described long before MRI technology became clinically available in the early 1980s. In the past, inspection of the human cortex was restricted to post-mortem analyses when fine sagittal slices were extremely difficult to achieve. Our own analysis of the human cortex utilizing both skull-stripped surface renderings and serial sagittal MRI inspection revealed that sulcal depth has an effect on the concurrence of the parallel and count-back methods for locating the AG. As was seen here, much of the natural variability in the human brain exists in deeper areas of the cortex. Certainly, this anatomical variability is not limited to what can be seen by the naked eye on the cortical surface.

Interruptions or breaks along the STS occurred in 17/40 (43\%) hemispheres. Of these breaks, 12/17 (71\%) occurred in the left hemisphere and 5/17 (29\%) in the right. This makes sense considering the typical higher degree of fissuration that is evident in the left temporal lobe compared to the right. Five brains had breaks in the STS that were anterior to the postcentral sulcus (PCS), all of which occurred in the left hemisphere. Six brains had breaks in the STS that were posterior to the PCS, three in the left hemisphere and three in the right. Furthermore, six brains had breaks in both the anterior and posterior STS, four in the left hemisphere and two in the right. Based on our examination, we found that the location (anterior vs. posterior) of a break in the STS had no clear association with changes 


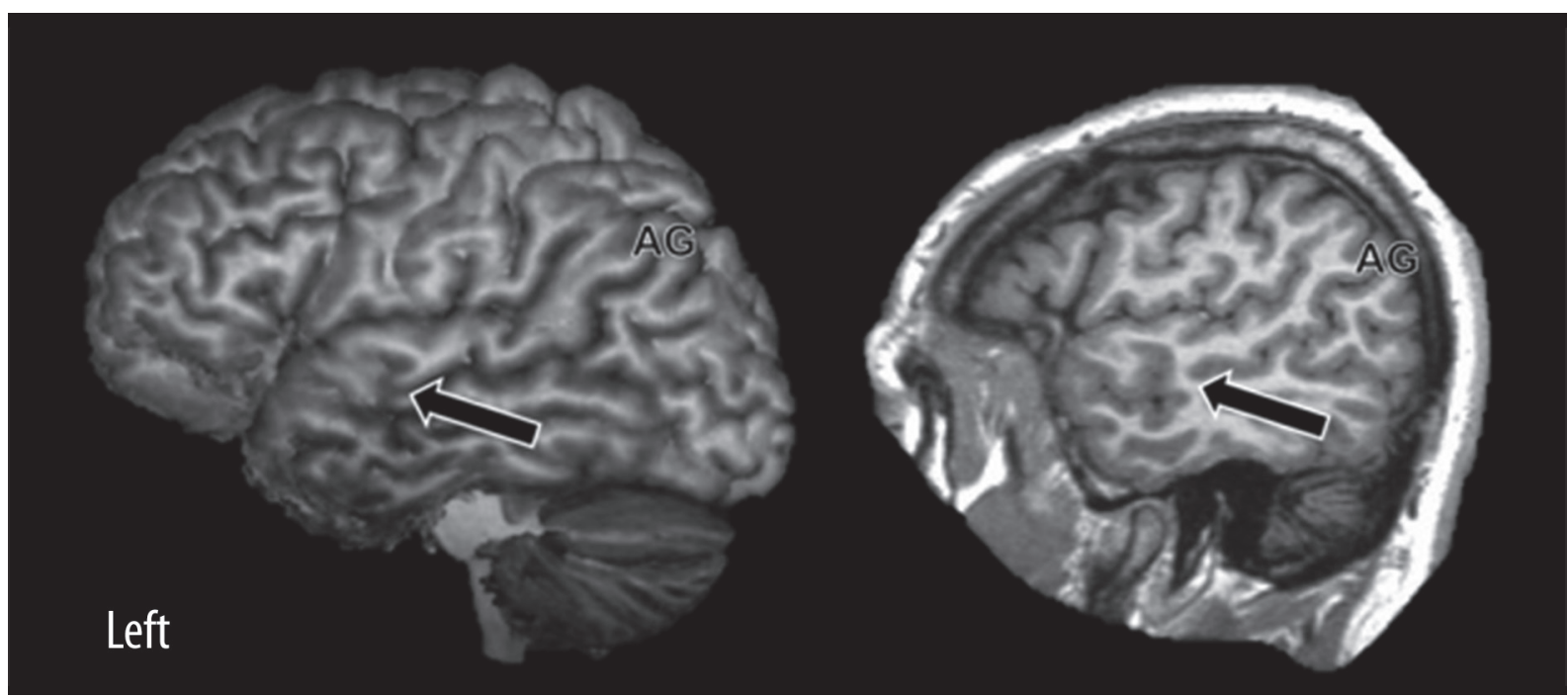

Figure 6. A break in the anterior portion of the STS (arrows) may not affect the location of the AG, as defined by the parallel and count-back methods. Images generated from data for subject OAS1_0101LH

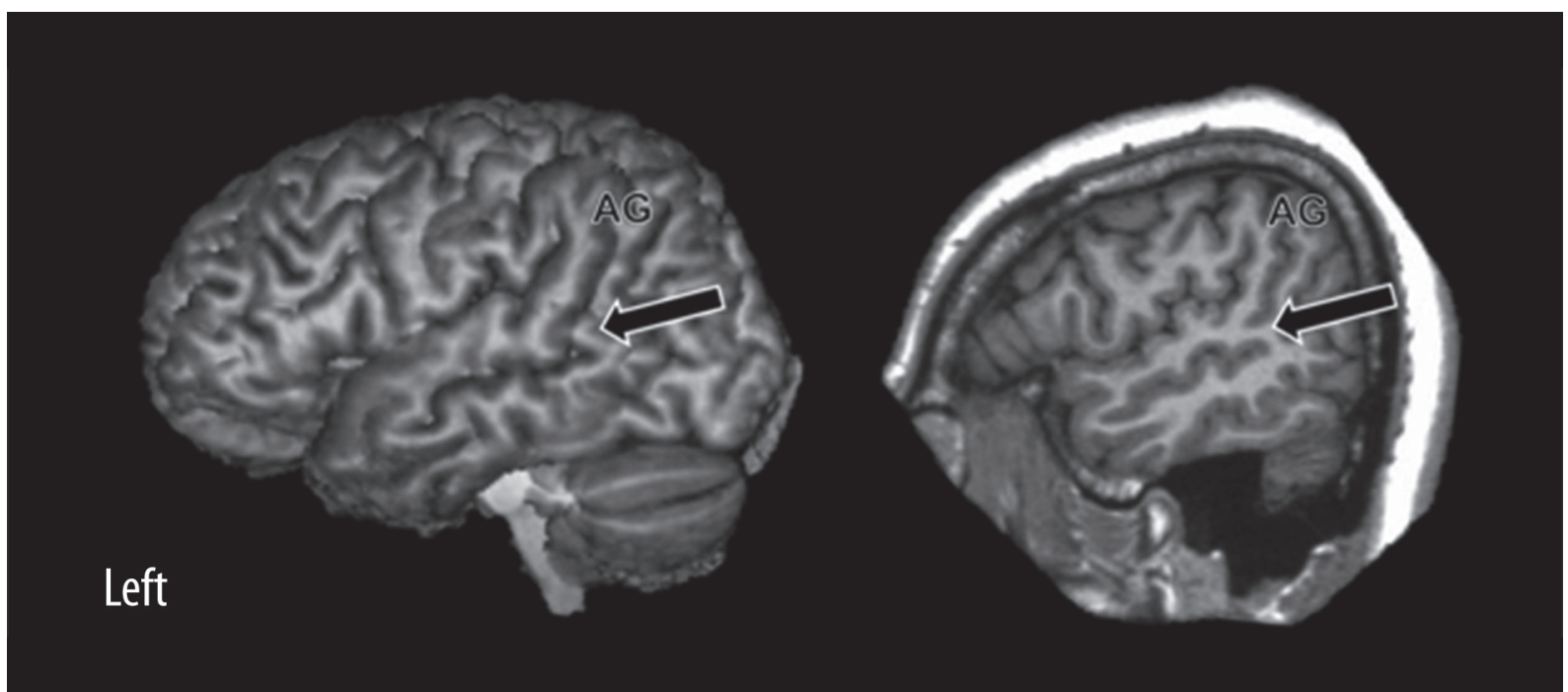

Figure 7. A break in the posterior portion of the STS (arrows) may not affect the location of the AG if one traces the STS posterodorsally, continuing past the break. Images generated from data for subject OAS1_0040LH

in morphology of the IPL, or the location of the AG (see Figures 6 and 7 for examples). Our finding of more frequent STS interruptions in the left hemisphere compared to right is consistent with that of Ochiai et al. [26] who scrutinized the morphology of the STS based on an ontogenic model of cortical gyration. These authors referred to the gyral interruptions of the STS as "plis de passage", an anatomical term created by the French anatomist Louise Pierre Gratiolet in 1854 to describe superficial gyri that interrupt major sulci in the brain.

Although we saw no clear association between the location of a break in the STS and morphology of the IPL, we still followed strict guidelines when comparing the parallel and count-back methods. For reliability purposes, in this study we considered breaks in the STS occurring posterior to the PCS to be the actual end of the STS. Discontinuities in this region of the STS sometimes contributed to anatomical ambiguity in the temporoparietal junction. Thus, in such instances the parallel and count-back methods were more likely to disagree than agree, because the actual location of the posterior termination of the STS was unclear (Figure 8).

In three hemispheres, agreement of the two methods was imperfect due to anatomical variations in the IPL $(0092 \mathrm{LH}$; 0045LH; 0051LH). In these particular cases, the region directly posterior to the SMG had a unique morphology in that the STS terminated at a location inferior and posterior to the SMG. This made it difficult to determine if the parallel and count-back methods agreed with each other because essentially only the superior half of the AG linedup posteriorly to the inferior half of the SMG (Figure 9).

Interestingly, for $30 \%$ of hemispheres at least some portion of the AG and SMG overlapped (12/40 hemispheres: 6 right, 6 left). Specifically, the anterior part of the AG shared the same gyrus as the posterior part of the SMG in these instances (Figure 10). 


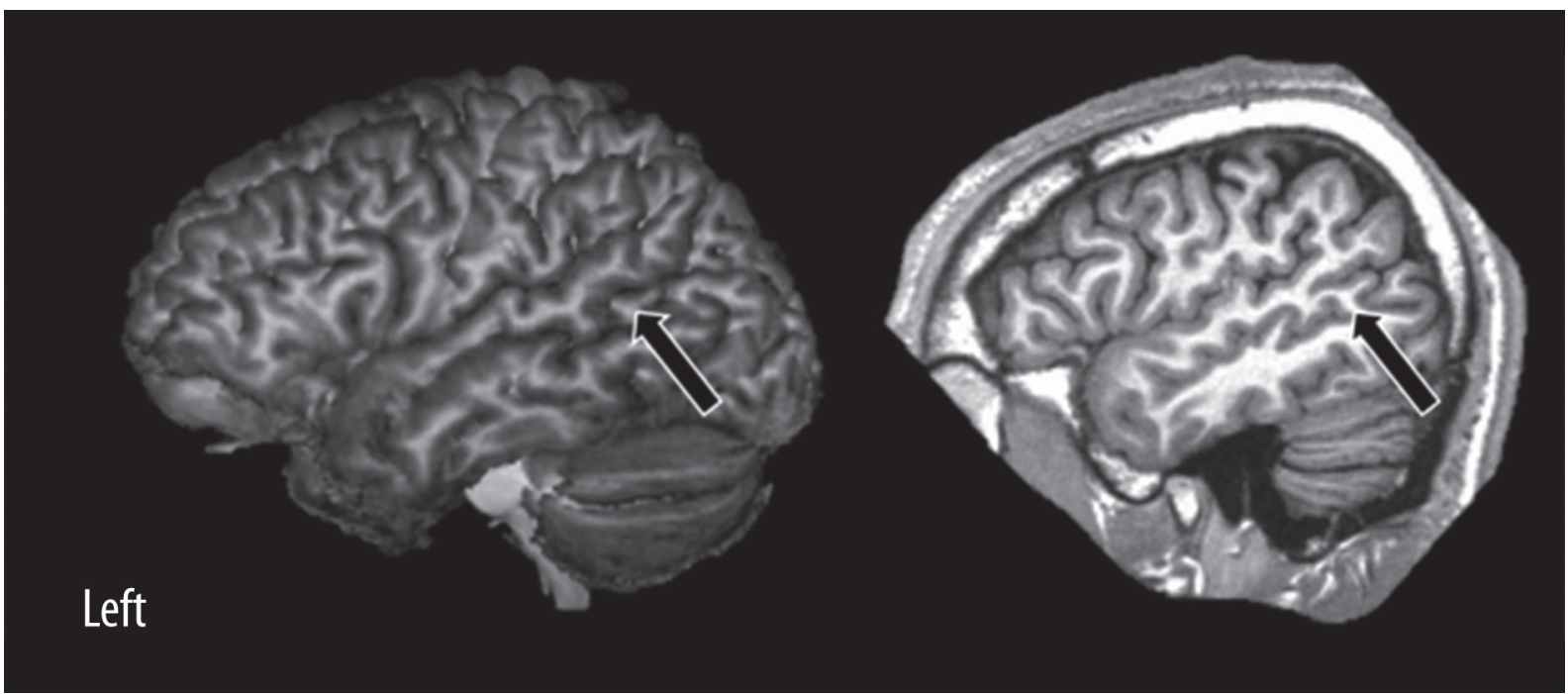

Figure 8. Interruptions in the superior temporal sulcus occurring posterior to the postcentral sulcus (arrows) sometimes create anatomical ambiguity in the inferior parietal lobule. This makes finding the AG problematic when employing the parallel and count-back methods. Images generated from data for subject OAS1_0092LH

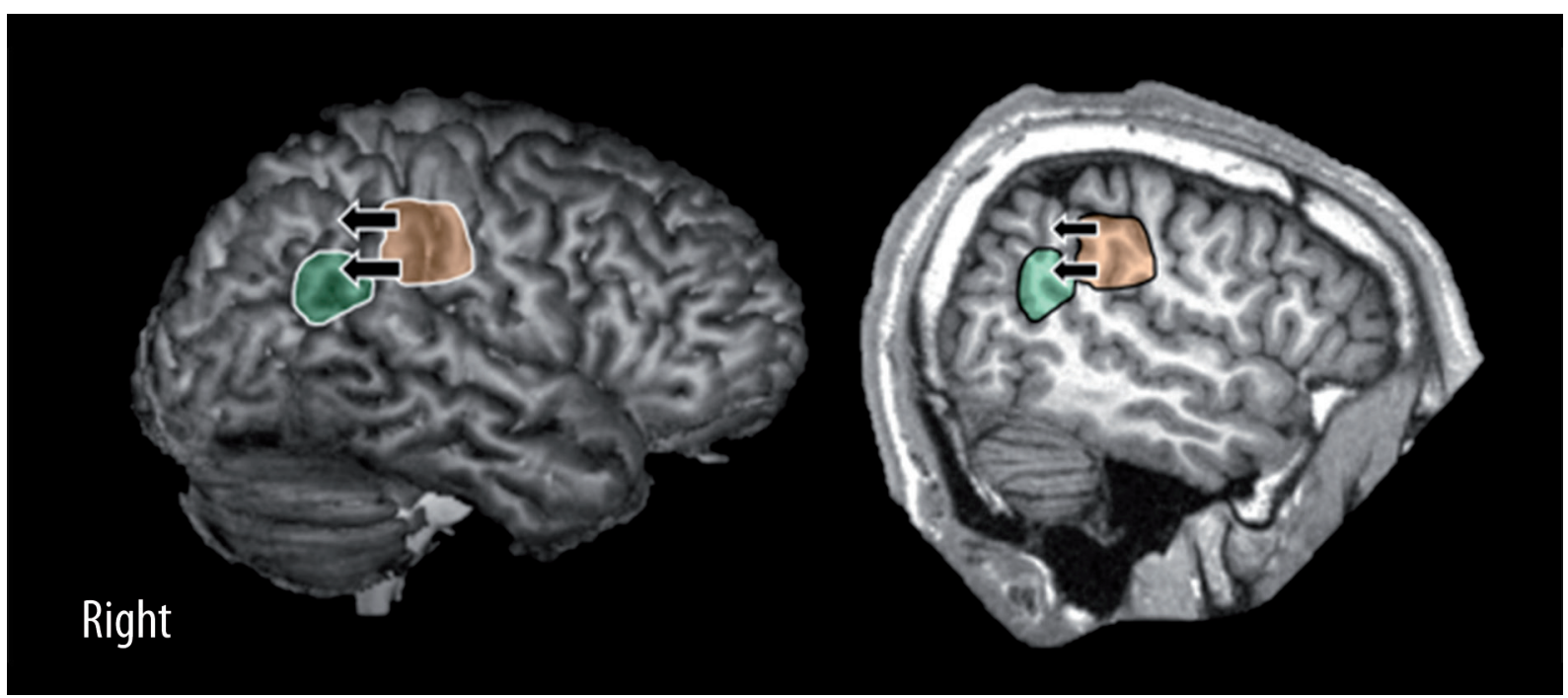

Figure 9. In this example (subject OAS1_0092RH, the superior portion of the AG is located directly behind the inferior portion of the SMG (bottom arrow). However, the gyrus that is immediately posterior to the superior portion of the SMG does not seem to be the AG (top arrow). Thus, here the parallel and count-back methods only partially agree on the location of the AG

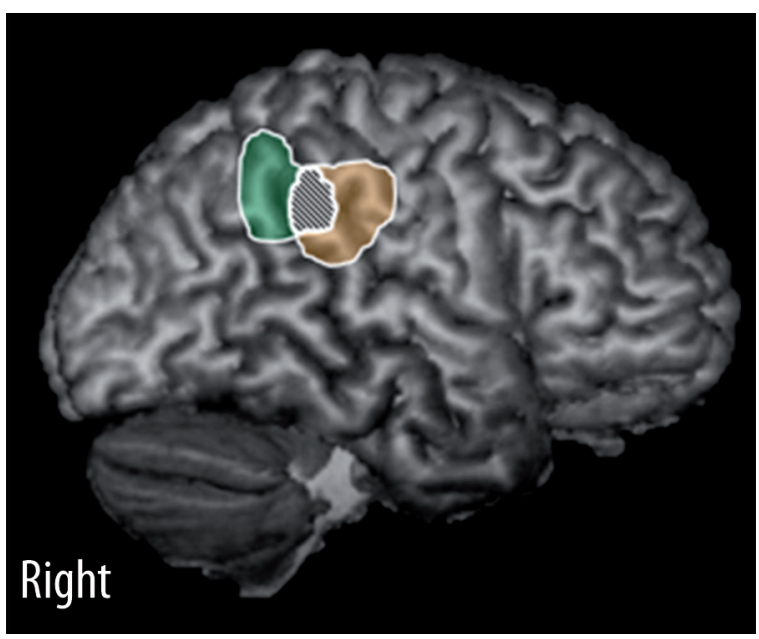

Lastly, the presence of a posterior ascending ramus of the SF sometimes creates another problem when trying to validate the two methods of AG demarcation. The sudden upwards course of the SF in the case of a posterior ascending ramus may create a pronounced separation between the SF and the STS in their posterior extensions (Figure 1). A greater separation between the SF and the STS is especially problematic when attempting to find agreement between both the parallel and count-back methods because, as mentioned previously, the concurrence of these two methods depends on presuming that sulci coincide.

Figure 10 . For $30 \%$ of the hemispheres studied, the $A G$ and SMG overlapped. In the example here (OAS1_0049RH), the anterior portion of the AG (green) and the posterior portion of the SMG (orange) share the same gyrus

() Journal of Hearing Science ${ }^{\circledR} \cdot 2016$ Vol. 6 · No. 2 


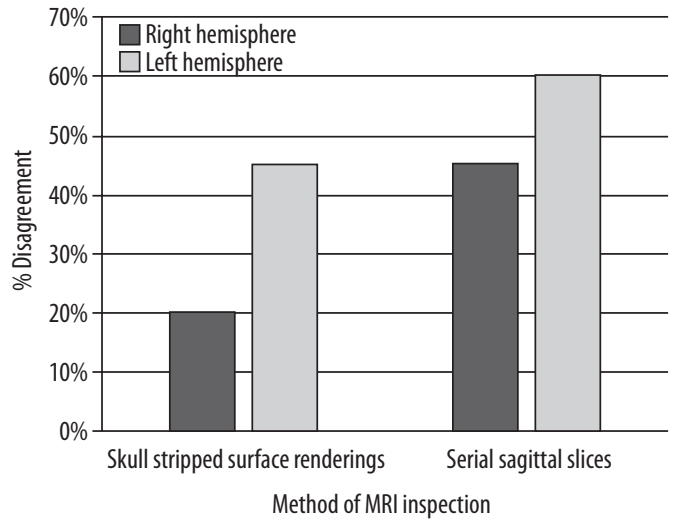

Figure 11. The frequency of disagreement between the parallel and count-back methods for location of the AG depended on the MRI inspection technique used. Disagreement occurred more often for the left hemisphere than the right and when the brain was inspected more medially (i.e., serial sagittal technique). The criterion for disagreement was a location differing by more than 10 voxels $(10 \mathrm{~mm})$

\section{Discussion}

After examining the surface of human brains, the countback and parallel methods for locating the AG disagreed in $45 \%$ and $20 \%$ of the left and right hemispheres, respectively. Additionally, when looking more medially (10-20 mm), the two methods for locating the AG were unreliable in $60 \%$ and $45 \%$ of the left and right hemispheres, respectively (Figure 11). Although in our small sample we identified poorer reliability in the left hemisphere than in the right, there was no statistically significant difference between methodological disagreement and hemisphere. We believe that with a larger sample size, a statistically significant difference between the hemispheres is likely to emerge.

A major reason we identified poor concurrence between the parallel and count-back methods is because the depth of the STS is not consistent along its anterior-to-posterior course, and is deeper in the right hemisphere compared to the left [26]. The shallow left STS produces more superficial gyral patterns, which create disruptions along the STS in the left hemisphere. These interrupting gyri affect the concurrence of the parallel and count-back methods, particularly when the interruptions occur caudal to the post-central sulcus which may create anatomical ambiguity in the temporoparietal junction. Our results showing more disagreement in the left hemisphere compared to the right are consistent with Steinmetz et al. [27], who report that the left perisylvian region is more variable than the right. These authors state that "the Sylvian fissure is an unreliable landmark with respect to inferior parietal structures (i.e., SMG and AG) especially in the left hemispheres". Since both the parallel and count-back methods depend on the morphology of the SF, new methods for finding the AG may be warranted. Currently, the questionable reliability of these two common methods for locating the AG makes determining the functions of the structure more challenging.

The auditory functions of the AG are often overlooked due to its surrounding structures. However, it may have a bigger auditory role than the data has so far shown. Further research on the AG is needed in order to construct a clearer picture of its auditory functions. Research involving central auditory function tests in individuals with lesions on the AG may lead to a more refined understanding of auditory processing deficits in this population. Due to the limited amount of research on auditory involvement of the AG in the right hemisphere, further investigation is needed to elucidate the role of the right AG in auditory processing and better define the previously suggested functional asymmetries.

\section{Conclusions}

In this study we attempted to determine the reliability of two common methods of locating the AG. The results suggest that 1) these methods seem to be less reliable in locating the AG in the left hemisphere than the right; and 2) the reliability of the methods does not hold-up as well when the brain is examined more medially. A larger sample size would help validate our results. Also, due to the substantial variability in sulcal and gyral patterns between brains, some AGs were easier to identify than others. This makes inter-rater reliability paramount for validating our results. Although we employed several cross-checks to ensure our data was accurate, it would have been better to have additional people involved in the inter-rater reliability process.

\section{Acknowledgements}

We gratefully acknowledge the use of OASIS data, which is supported by grants P50 AG05681, P01 AG03991, R01 AG021910, P20 MH071616, and U24 RR021382. A Royal Arch Research Assistance grant is also acknowledged.

\section{References:}

1. Démonet JF, Chollet F, Ramsay S, Cardebat D, Nespoulous JL, Wise $\mathrm{R}$ et al. The anatomy of phonological and semantic processing in normal subjects. Brain, 1992; 115: 1753-68.

2. Démonet JF, Price C, Wise R, Frackowiak RSJ. Differential activation of right and left posterior sylvian regions by semantic and phonological tasks: a positron-emission tomography study in normal human subjects. Neurosci Lett, 1994; 182: 25-28.

3. Price CJ, Moore CJ, Humphreys GW, Wise RJ. Segregating semantic from phonological processes during reading. J Cogn Neurosci, 1997; 9: 727-33.
4. Mummery CJ, Patterson K, Hodges JR, Price CJ. Functional neuroanatomy of the semantic system: divisible by what? J Cogn Neurosci, 1998; 10: 766-77.

5. Devlin JT, Matthews PM, Rushworth MF. Semantic processing in the left inferior prefrontal cortex: a combined functional magnetic resonance imaging and transcranial magnetic stimulation study. J Cogn Neurosci, 2003;15: 71-84.

6. Seghier ML, Fagan E, Price CJ. Functional subdivisions in the left angular gyrus where the semantic system meets and diverges from the default network. J Neurosci, 2010; 30: 16809-17. 
7. Brodmann K. Brodmann's Localisation in the Cerebral Cortex. Trans. Garey LJ. $3^{\text {rd }}$ ed. London: Springer Science \& Business Media; 2007.

8. Lee H1, Devlin JT, Shakeshaft C, Stewart LH, Brennan A, Glensman J et al. Anatomical traces of vocabulary acquisition in the adolescent brain. J Neurosci, 2007; 27: 1184-89.

9. Webster D. Neuroscience of communication. $2^{\text {nd }}$ ed. San Diego: Singular Publishing; 1999.

10. Musiek F, Baran J. The auditory system: anatomy, physiology and clinical correlates. Boston: Pearson Education; 2007.

11. Rubens AB. Anatomical asymmetries of human cerebral cortex. In: Harnad S, Doty RW, Goldstein L, Jaynes J, Krauthamer G (eds.), Lateralization in the nervous system. New York: Academic Press; 1977, 503-13.

12. Tzourio-Mazoyer N, Landeau B, Papathanassiou D. Automated anatomical labeling of activations in SPM using a macroscopic anatomical parcellation of the MNI MRI single-subject brain. Neuroimage, 2002;15: 273-89.

13. Caspers S, Eickhoff SB, Geyer S, Scheperjans F, Mohlberg H, Zilles $\mathrm{K}$ et al. The human inferior parietal lobule in stereotaxic space. Brain Struct Funct, 2008; 212: 481-95.

14. Eggert LD, Sommer J, Jansen A, Kircher T, Konrad C. Accuracy and reliability of automated gray matter segmentation pathways on real and simulated structural magnetic resonance images of the human brain. PLoS One, 2012; 7(9): e45081.

15. Eberstaller O. Das Stirnhirn. Wein and Leipzig: Urban and Schwarzenberg; 1890.

16. Naidich TP, Valavanis AG, Kubik S. Anatomic relationships along the low-middle convexity: part I - normal specimens and magnetic resonance imaging. Neurosurg, 1995; 36: 517-32.

17. Brodmann K. Brodmann's Localisation in the Cerebral Cortex. Trans. Garey LJ. Springer Science \& Business Media. 2007; chapter IV, p. 117.
18. Ribas GC. The cerebral sulci and gyri. Neurosurgical Focus, 2010; 28: E2.

19. Seghier ML. The angular gyrus multiple functions and multiple subdivisions. Neuroscientist, 2013;19(1): 43-61.

20. Grabner RH, Ansari D, Koschutnig K, Reishofer G, Ebner F. The function of the left angular gyrus in mental arithmetic: evidence from the associative confusion effect. Human Brain Mapping, 2013; 34(5): 1013-24.

21. Berry I, Démonet JF, Warach S, Viallard G, Boulanouar K, Franconi JM et al. Activation of association auditory cortex demonstrated with functional MRI. Neuroimage, 1995; 2: 215-19.

22. Binder JR, Frost JA, Hammeke TA, Rao SM, Cox RW. Function of the left planum temporale in auditory and linguistic processing. Brain, 1996; 119: 1239-47.

23. Zhang Z, Shi J, Yuan Y, Hao G, Yao Z, Chen N. Relationship of auditory verbal hallucinations with cerebral asymmetry in patients with schizophrenia: an event-related fMRI study. J Psychiat Res, 2008; 42: 477-86.

24. Marcus DS, Wang TH, Parker J, Csernansky JG, Morris JC, Buckner RL. Open access series of imaging studies (OASIS): cross-sectional MRI data in young, middle aged, nondemented, and demented older adults. J Cogn Neurosci, 2007; 19: 1498-507.

25. Connolly CJ. External morphology of the primate brain. Springfield (IL): C.C. Thomas; 1950.

26. Ochiai T1, Grimault S, Scavarda D, Roch G, Hori T, Rivière D et al. Sulcal pattern and morphology of the superior temporal sulcus. Neuroimage, 2004;22: 706-19.

27. Steinmetz H, Ebeling U, Huang Y, Kahn T. Sulcus topography of the parietal opercular region: an anatomic and MR study. Brain Lang, 1990; 38: 515-33. 